\title{
Skullcapflavone I inhibits proliferation of human colorectal cancer cells via down-regulation of miR-107 expression
}

\author{
W. ZHANG, W. LI, X. HAN* \\ Department of Gastroenterology, Shengli Oilfield Central Hospital, Dongying, China \\ *Correspondence: hxue320@sina.com
}

Received April 27, 2018 / Accepted August 15, 2018

\begin{abstract}
Colorectal cancer (CRC) is a common malignant tumor with high global increase and mortality. While Skullcapflavone I has been reported to exert anti-tumor effect in several cancers, its role in CRC has not previously been investigated. Recent studies have also demonstrated that microRNA-107 (miR-107) and tropomyosin alpha-1 (TPM1) are important regulators of cancer cell proliferation, but it remains unclear if these are involved in regulating the effect of Skullcapflavone I on CRC cells. This study therefore assessed the effects of Skullcapflavone I on CRC cell proliferation and investigated miR-107 and TPM1 regulatory effects on this process. The results showed that Skullcapflavone I significantly suppressed cell proliferation and viability and down-regulated PCNA and Cyclin D1protein levels. It also down-regulated miR-107 expression which then promoted TPM1 expression, but miR-107 over-expression abolished Skullcapflavone I anti-proliferative effects. Furthermore, Skullcapflavone I inhibited the activations of MEK/ERK and NF- $\kappa$ B signal pathway activation by regulating TPM1 in HCT116 cells. These results demonstrated that Skullcapflavone I increased the expression of TPM1 by downregulating miR-107 and inhibiting the MEK/ERK and NF- $\kappa B$ signal pathways. It then inhibited HCT116 cell proliferation, and therefore Skullcapflavone I may provide new methodology in colorectal cancer treatment.
\end{abstract}

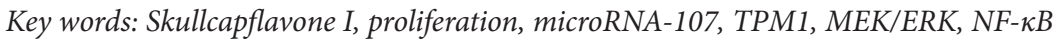

Colorectal cancer (CRC) is a common malignant tumor of the gastrointestinal tract which develops in the colon or rectum $[1,2]$. The disease most often occurs in males, especially in those between 40 and 70 years of age [3]. The pathogenic mechanisms of CRC remain obscure, but may be due to genetic and environmental factors such as obesity, smoking, alcohol, red and processed meat, insulin resistance and inflammatory bowel diseases $[4,5]$. The clinical manifestations include hematochezia, diarrhea, abdominal pain, anemia and weight loss [6]. While the current treatment is surgery, radiation therapy, chemotherapy and targeted therapy [7], 5-year survival remains unsatisfactory. Therefore, it is necessary to find more effective treatment for CRC.

Scutellaria baicalensis Georgi (S. baicalensis) is a traditional herbal medicine which has been widely used for clinical treatment of respiratory tract infection, acute dysentery, viral hepatitis and allergic and gynecological diseases $[8,9]$. Recent, studies have also demonstrated that flavones constitute its active components [10], and that it has antioxidant, anti-viral, anti-bacterial, anti-inflammatory and anti-tumor properties $[9,11]$.
Skullcapflavone I's flavone attributes are anti-inflammatory and anti-tumor ability. Although Chandrasekaran et al. [12] found that Skullcapflavone I exhibited anti-inflammatory effects by modulating different inflammatory mediators in J774A.1, HL-60 and RBL-2H3 cells [12] and Park et al. [13] reported that Skullcapflavone I induced T-HSC/ Cl-6 cell apoptosis via activation of caspase-3 and caspase-9. However, Skullcapflavone I's functional effects in CRC have not been fully investigated.

The important miR-107 presence has been reported in diseases. This includes Alzheimer's and neuro-degenerative diseases and cancers [14-16], and its tumor-promoting or tumor-suppressing effect has been confirmed in many recent studies $[17,18]$. While miR-107 performs important roles in regulating multiple biological processes in CRC has not been investigated.

Tropomyosin alpha- 1 chain (TPM1) is a tumor suppressor in various cancers $[19,20]$, but its effect in CRC also remains undetermined. Therefore, we investigated Skullcapflavone I's influence in CRC and HCT116 cell regulation by miR-107 and TPM1. We then analyzed signal pathways of mitogen- 
activated protein kinase (MAPK) kinase (MEK)/extracellular signal-regulated kinase (ERK) and nuclear factor kappa $\mathrm{B}(\mathrm{NF}-\kappa \mathrm{B})$ for potential mechanisms; and our results are expected to provide the basis for Skullcapflavone I clinical treatment in CRC.

\section{Materials and methods}

Cell culture and treatment. Human colon carcinoma cell line HCT116 was obtained from the American Type Culture Collection (ATCC, Manassas, VA, USA). The cells were cultured in Roswell Park Memorial Institute (RPMI)-1640 medium (Sigma, St Louis, MO, USA) supplemented with 10\% fetal bovine serum (FBS) at $37^{\circ} \mathrm{C}$ in a humidified atmosphere containing $5 \% \mathrm{CO}_{2}$. Skullcapflavone I was purchased from Sigma-Aldrich (Sigma, USA). Prior to use, Skullcapflavone I was dissolved in DMSO and different concentrations of Skullcapflavone I $(5,10,15$ and $20 \mu \mathrm{g} / \mathrm{ml})$ were used to treat HCT116 cells in following experiments. The cells were equally treated with the same quantity of solvent DMSO as the control and time was $24 \mathrm{~h}$, except for the cells featured in Figure 1A.

Trypan blue staining assay. HCT116 cells $\left(1 \times 10^{3}\right.$ cells/ well) were seeded in 96-well plates and treated with 5, 10, 15 and $20 \mu \mathrm{g} / \mathrm{ml}$ of Skullcapflavone I at $37^{\circ} \mathrm{C}$ and $5 \% \mathrm{CO}_{2}$. They were then stained with $0.4 \%$ trypan blue (Invitrogen, CA, USA) and cell were counted by Countess Automated Cell Counter (Invitrogen) after 6, 12, 24, 36, 48 and $72 \mathrm{~h}$.

CCK-8 assay. CCK-8 (Dojindo Molecular Technologies, Gaithersburg, MD) assay examined cell viability. Briefly, HCT116 cells $\left(5 \times 10^{3}\right.$ cells/well $)$ were seeded in 96 -well plates and treated with different concentrations of Skullcapflavone I $(5,10,15$ and $20 \mu \mathrm{g} / \mathrm{ml})$ for $24 \mathrm{~h}, 10 \mu \mathrm{l} \mathrm{CCK}-8$ solution was then added to the culture medium to continue incubating for $1 \mathrm{~h}$ at $37^{\circ} \mathrm{C}$ in humidified $95 \%$ air and $5 \% \mathrm{CO}_{2}$. The optical density (OD) was measured at $450 \mathrm{~nm}$ by Microplate Reader (Bio-Rad, CA, USA).

Cell transfection. MiR-107 mimic and mimic control were synthesized by GenePharma Co. (Shanghai, China). The TPM1 expression vector was constructed by sub-cloning the full-length TPM1 sequence into pEX-2 plasmids (GenePharma). TPM1 targeted small interfering (siRNA) was also synthesized by Genepharma. For transfection, HCT116 cells were cultured in 6-well plate for $24 \mathrm{~h}$ at $37^{\circ} \mathrm{C}$ and transfected with miR-107 mimic, pEX-TPM1 or si-TPM1 expression vectors. All cell transfections were implemented by lipofectamine 3000 reagent (Life Technologies Corporation, Carlsbad, CA, USA) according to manufacturer instructions.

Real-time quantitative PCR (RT-qPCR). Total RNA was extracted from HCT116 cells using Trizol reagent (Life Technologies Corporation, Carlsbad, CA, USA) according to manufacturer instructions. Sample $50 \mathrm{ng}$ RNA was reverse transfected to complementary DNA (cDNA) by Transcriptor First Strand cDNA Synthesis Kit (Roche, USA), and RT-qPCR was performed with Taqman MicroRNA Reverse Transcription Kit and Taqman Universal Master Mix II with the TaqMan MicroRNA Assay. Data was normalized to U6 (Applied Biosystems, Foster City, CA, USA) and measured by $2^{-\Delta \Delta \mathrm{CT}}[21]$.

Western blot. Total protein from HCT116 cells was extracted by radio immune precipitation (RIPA) lysis buffer (Beyotime Biotechnology, Shanghai, China) supplemented with protease inhibitors (Roche, Basle, Switzerland). The concentrations of these proteins were measured by $\mathrm{BCA}^{\mathrm{mm}}$ Protein Assay Kit (Pierce, Appleton, WI, USA). Bio-Rad Bis-Tris Gel system then performed Western blot assay according to manufacturer instructions. Proteins $(20 \mu \mathrm{g})$ were added to the $10 \%$ sodium dodecyl sulfate polyacrylamide gel electrophoresis (SDS-PAGE) and then transferred onto a polyvinylidene fluoride (PVDF) membrane. Subsequently, primary antibodies of proliferating cell nuclear antigens were prepared in 5\% blocking buffer and incubated with the membrane at $4{ }^{\circ} \mathrm{C}$ overnight. These were: PCNA, ab152112, dilution of 1:500), Cyclin D1 (ab61758, dilution of 1:500), TPM1 (ab7785, dilution of 1:100), phosphorylated (p)-MEK (ab78123, dilution of 1:2000), MEK (ab131517, dilution of 1:500), phosphorylated (p)-ERK (ab214362, dilution of 1:100), ERK (ab196883, dilution of 1:500), phosphorylated (p)-IкBa (ab92700, dilution of $1: 500$ ), IкBa (ab32518, dilution of $1: 1000)$ and $\beta$-actin (ab8227, dilution of 1:1000), (all from Abcam, Cambridge, UK) After washing, the membranes were incubated with horseradish peroxidase (HRP)-conjugated goat anti-rabbit IgG (ab205718) at 1:2,000 at room temperature for $1 \mathrm{~h}$. Blots were finally examined by ECL system (Amersham Pharmacia, Piscataway, NJ, USA) and quantitative band analysis was accomplished by Image $\mathrm{Lab}^{\mathrm{Tm}}$ Software (Bio-Rad, Shanghai, China).

Statistical analysis. Graphpad statistical software completed statistical analysis, with data expressed as mean + standard deviation (SD). One-way analysis of variance (ANOVA) was performed to analyze $p$-values, and $p$-value less than 0.05 was statistically significant. All experiments were repeated three times.

\section{Results}

Skullcapflavone I inhibited HCT116 cell proliferation. To explore the effect of Skullcapflavone I on cell proliferation of HCT116 cells, the proliferation rate was detected by trypan blue staining assay after treatment with different concentrations of Skullcapflavone I $(5,10,15$, and $20 \mu \mathrm{g} / \mathrm{ml})$. Figure 1A highlighted that Skullcapflavone I decreased the living cell numbers at 36,48 and $72 \mathrm{~h}$ in a dose-dependent manner. The significant difference appeared at $72 \mathrm{~h}$ treatment $(p<0.05$ or $p<0.01)$. The results in Figure $1 B$ revealed that cell viability was statistically suppressed by Skullcapflavone I at 15 and $20 \mu \mathrm{g} / \mathrm{ml}$ compared to controls $(\mathrm{p}<0.05)$. $20 \mu \mathrm{g} / \mathrm{ml}$ of Skullcapflavone I then treated HCT116 cells in following experiments. Western blot results showed that the protein levels of PCNA and Cyclin D1 were notably reduced 
A

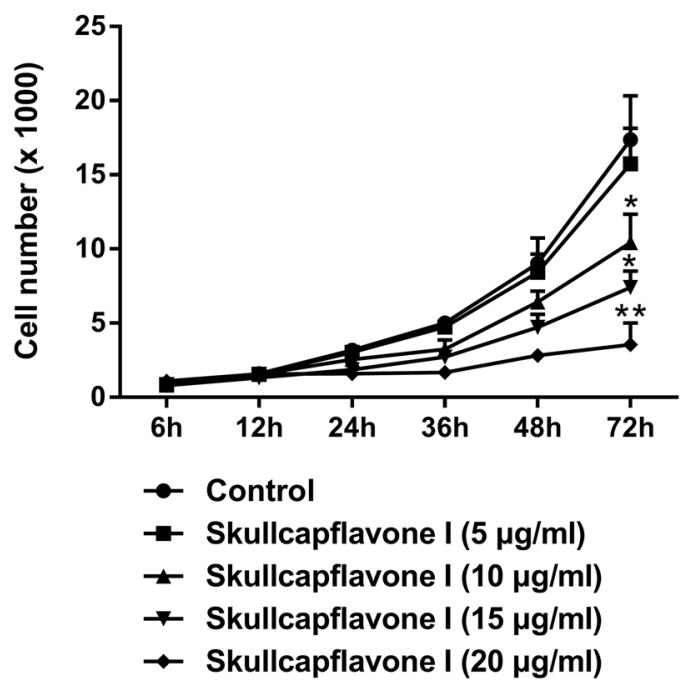

C

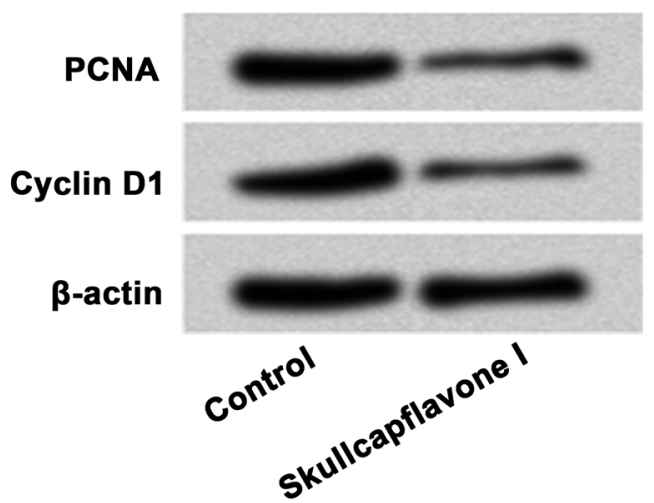

B

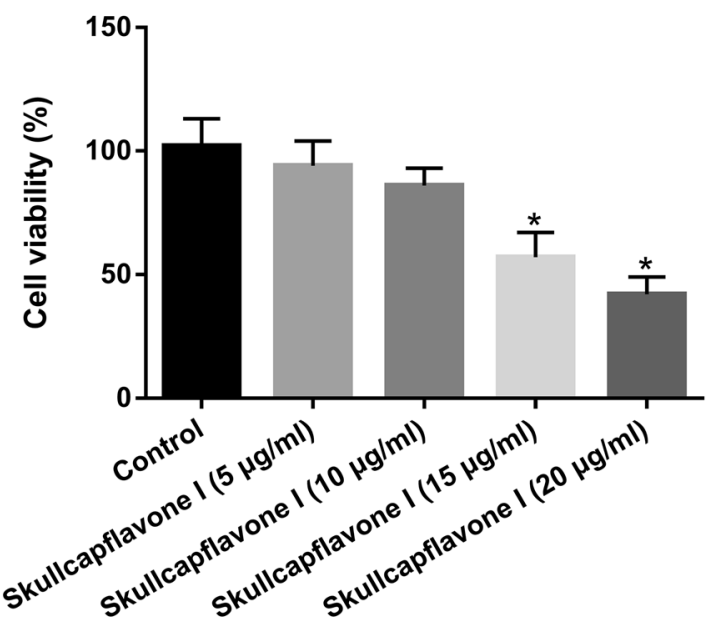

Control

Skullcapflavone I

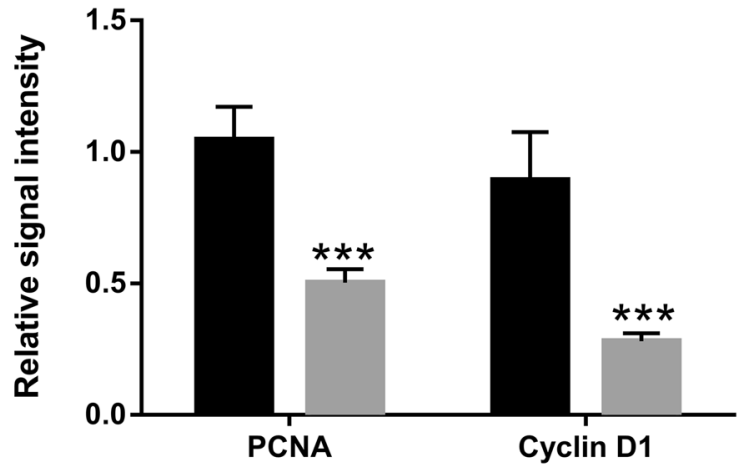

Figure 1. Skullcapflavone I inhibited cell proliferation of HCT116 cells. A) The proliferation rate was significantly reduced by Skullcapflavone I in a dose-dependent manner at $72 \mathrm{~h}$ treatment time. B) Cell viability was suppressed by Skullcapflavone I; C) The protein levels of PCNA and Cyclin D1 were reduced by Skullcapflavone I. Data is presented as the mean \pm SD of three independent experiments; ${ }^{*} p<0.05 ;{ }^{* *} p<0.01 ;{ }^{* * *} p<0.001$.

by Skullcapflavone I ( $<<0.001$, Figure $1 \mathrm{C})$; thus indicating that Skullcapflavone I inhibited HCT116 cell proliferation.

Skullcapflavone I down-regulated miR-107 expression. The expression level of miR-107 in HCT116 cells was detected by RT-qPCR after treatment with $20 \mu \mathrm{g} / \mathrm{ml}$ Skullcapflavone I. Figure 2 showed that Skullcapflavone I significantly reduced the expression level of miR-107 compared to controls $(\mathrm{p}<0.01)$; thereby confirming Skullcapflavone I reduced miR-107 expression in HCT116 cells.

Skullcapflavone I suppressed cell proliferation by downregulating miR-107. We established that Skullcapflavone I suppressed miR-107 expression, and therefore consider that miR-107 is involved in regulating HCT116 cell proliferation. To prove this, miR-107 mimic and mimic control were transfected into HCT116 cells to regulate miR-107 expression. Figure 3A showed that miR-107 expression was prominently increased in miR-107 mimic-transfected cells

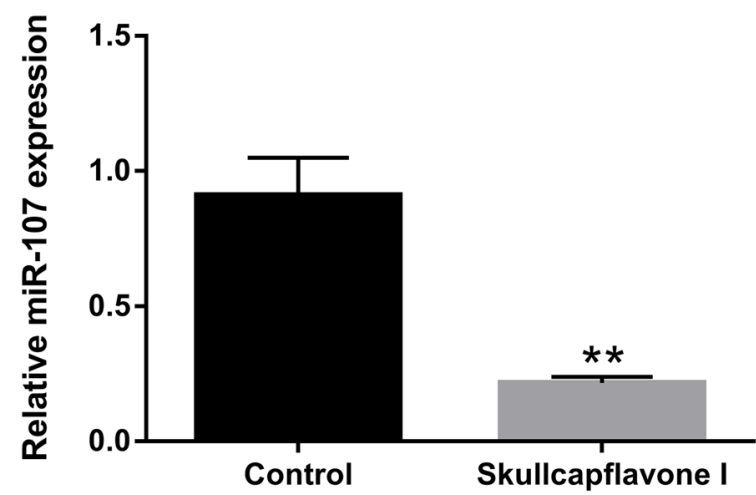

Figure 2. Skullcapflavone I down-regulated the expression of miR-107. HCT116 cells were treated with $20 \mu \mathrm{g} / \mathrm{ml}$ of Skullcapflavone I for $24 \mathrm{~h}$. RT-qPCR assay revealed that the expression level of miR-107 was significantly decreased by Skullcapflavone in HCT116 cells. Data is presented as the mean \pm SD of three independent experiments; ${ }^{\star *} \mathbf{p}<0.01$. 

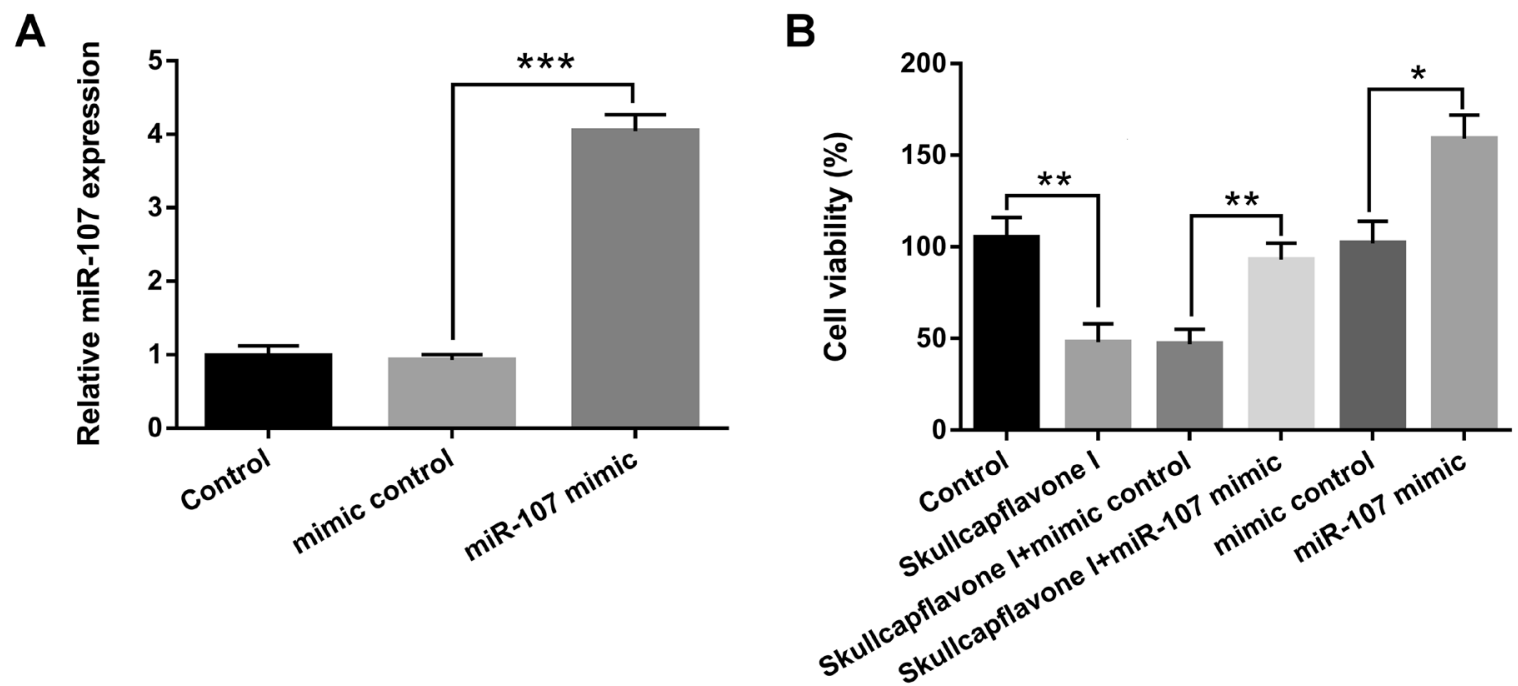

Figure 3. Skullcapflavone I suppressed cell proliferation by down-regulating miR-107. HCT116 cells were transfected with miR-107 mimic and mimic control. A) The expression level of miR-107 was significantly up-regulated by miR-107 mimic; B) cell viability was promoted by Skullcapflavone I + miR-107 mimic compared with Skullcapflavone $I+$ mimic control. Data is presented as the mean \pm SD of three independent experiments; ${ }^{\star \star}$ p $<0.01$; ${ }^{* * *} \mathbf{p}<0.001$.

A
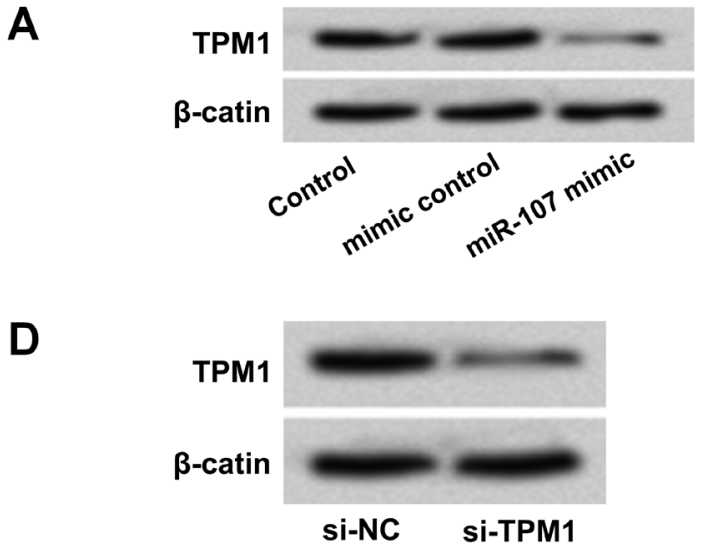

E

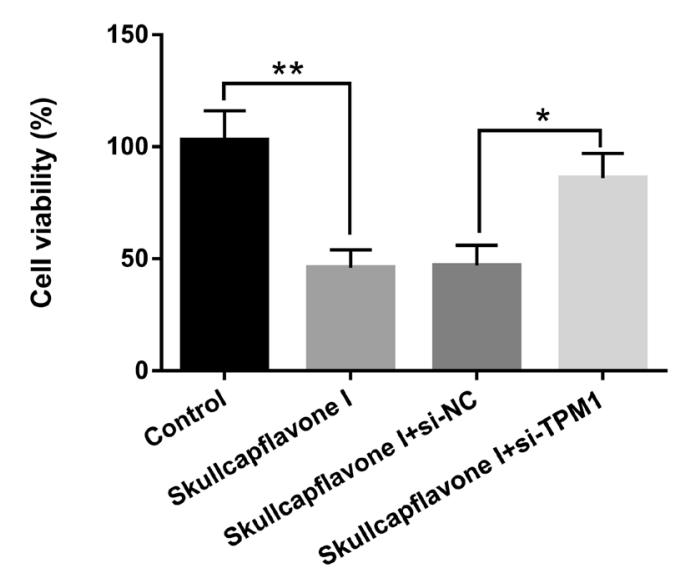

B

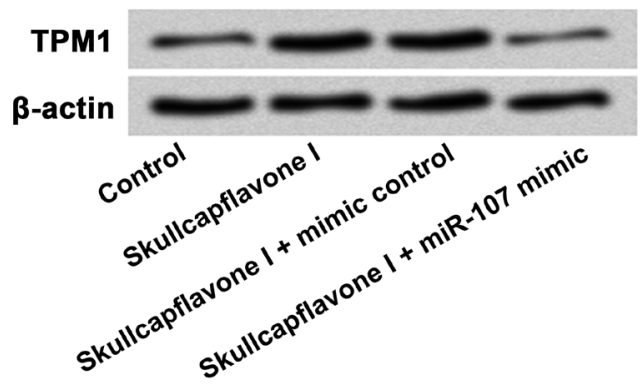

C

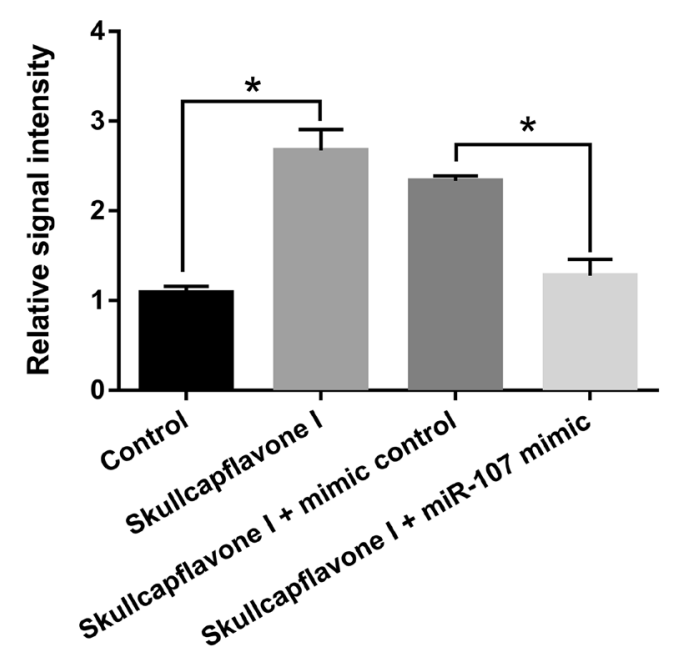

Figure 4. Skullcapflavone I promoted TPM1 by down-regulation of miR-107. HCT116 cells were transfected with miR-107 mimic and mimic control. A) The protein level of TPM1 was notably down-regulated in miR-107 mimic-transfected cells; B and C) the protein level of TPM1 was significantly reduced by Skullcapflavone I + miR-107 mimic compared to Skullcapflavone I + mimic control. HCT116 cells were transfected with si-TPM1 and si-NC, and D) TPM1 silencing decreased the protein level of TPM1 in HCT116 cells; E) cell viability was increased by Skullcapflavone I + si-TPM1 compared to Skullcapflavone I + si-NC. Data is presented as the mean \pm SD of three independent experiments; ${ }^{\star} p<0.05,{ }^{\star *} p<0.01$. 
compared to the mimic control group $(p<0.001)$; thus exhibiting a well transfection efficiency and that miR-107 mimic use was appropriate for following experiments. HCT116 cell viability was then examined by CCK- 8 . While this was obviously decreased by Skullcapflavone I $(\mathrm{p}<0.001)$, viability was increased by miR-107 over-expression $(\mathrm{p}<0.05)$. When co-treated with Skullcapflavone I and miR-107 mimic, cell viability was significantly enhanced compared to the Skullcapflavone $\mathrm{I}+$ mimic control group $(\mathrm{p}<0.01$, Figure $3 \mathrm{~B})$. This confirms that Skullcapflavone I inhibits HCT116 cell proliferation by down-regulating miR-107.

Skullcapflavone I promotes TPM1 by down-regulating miR-107. TPM1 has been reported a tumor suppressor in several diseases through regulating cell proliferation [22, 23]. However, the effect of TPM1 on CRC has not been investigated, so we examined the relationship between Skullcapflavone I, miR-107 and TPM1 in HCT116 cells. The miR-107 mimic and mimic controls were transfected in HCT116 cells, and the TPM1 protein level examined. Figure 4A revealed miR-107 over-expression notably down-regulated TPM1 protein level compared to mimic controls. After treatment with $20 \mu \mathrm{g} / \mathrm{ml}$ Skullcapflavone I for $24 \mathrm{~h}$, TPM1 protein level was measured by Western blot; and Figures $4 \mathrm{~B}$ and $\mathrm{C}$ highlighted that Skullcapflavone I + miR-107 mimic notably reduced TPM1 protein level compared to Skullcapflavone I + the mimic control group; thus establishing that Skullcapflavone I could promote TPM1 by down-regulating miR-107 in HCT116 cells.

To further explore the effect of TPM1 on cell proliferation of HCT116 cells, the expression vectors of si-TPM1 and si-NC were transfected into HCT116 cells. Western blot showed that TPM1 protein level was obviously reduced in si-TPM1-transfected cells (Figure 4D). CCK-8 assay then identified that TPM1 silencing significantly increased cell viability in Skullcapflavone I-treated HCT116 cells $(p<0.05$, Figure 4E), suggesting that TPM1 silencing reversed the inhibitory effect of Skullcapflavone I on cell viability.

Skullcapflavone I blocked MEK/ERK and NF-кB signal pathways by regulating TPM1. The MEK/ERK and NF- $\kappa \mathrm{B}$ signaling pathways are important mediators of cell proliferation [24], so Western blot assessed their effect on HCT116 cells transfected with pEX-TPM1 and its controls. Figure 5 showed that TPM1 over-expression remarkably decreased the protein levels of phosphorylated MEK, ERK
A

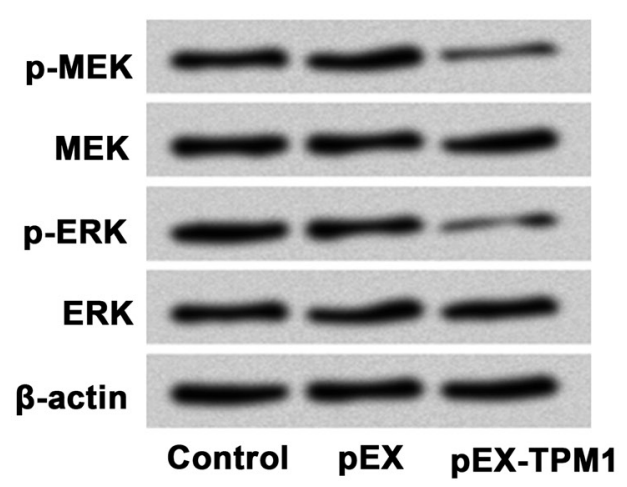

B

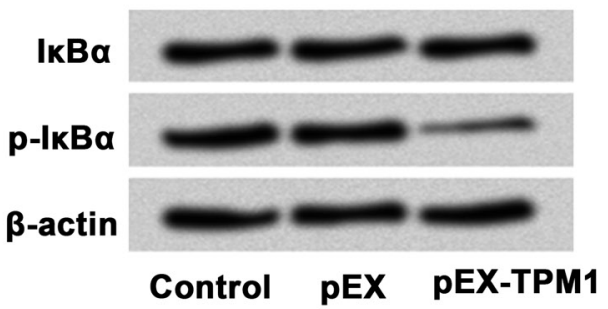

Control pEX pEX-TPM1
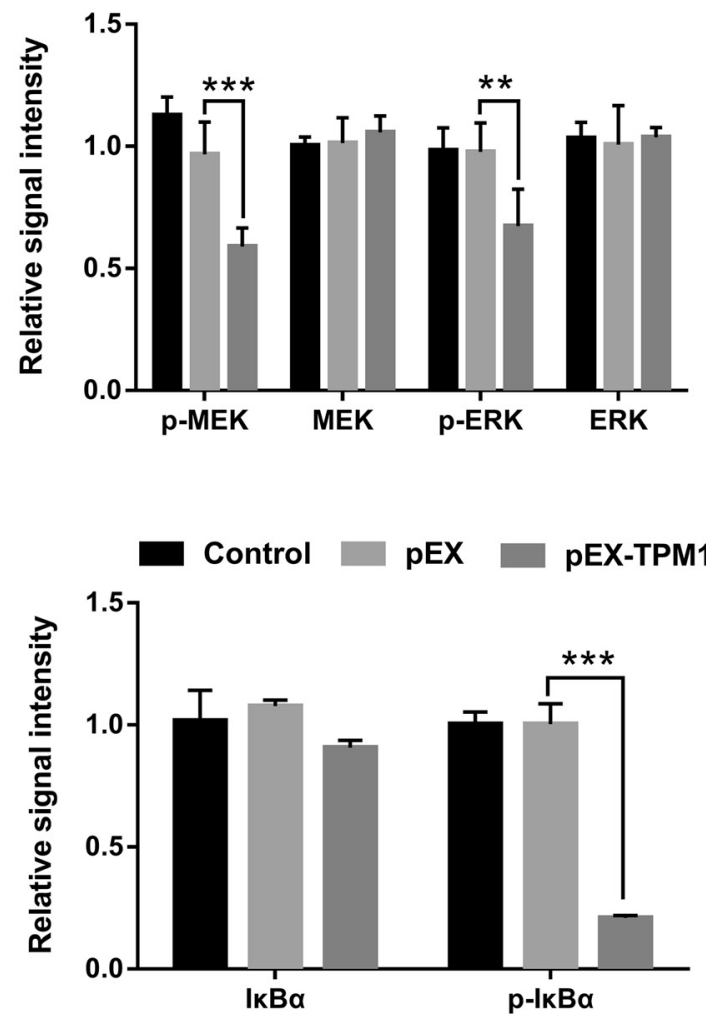

Figure 5. TPM1 blocked MEK/ERK and NF-ęB signal pathways. HCT116 cells were transfected with pEX-TPM1 and its control. A) The protein levels of MEK/ERK signal pathways factors were suppressed by over-expression of TPM1; B) the protein levels of NF- $\mathrm{kB}$ signal pathway factors were suppressed by over-expression of TPM1. Data is presented as the mean \pm SD of three independent experiments; ${ }^{\star *} p<0.01 ;{ }^{\star * *} p<0.001$. 




B

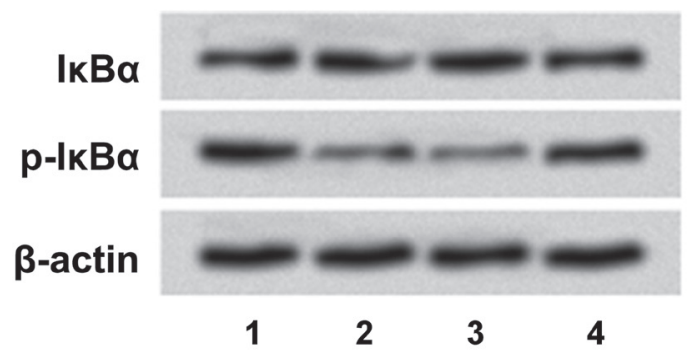

Figure 6 Skullcapflavone I inhibited the activations of MEK/ERK and NF$\kappa B$ signal pathways by regulation of TPM1. HCT116 cells were transfected with si-TPM1 and si-NC, and then treated with Skullcapflavone I (20 $\mu \mathrm{g} / \mathrm{ml}$ ) for $24 \mathrm{~h}$. A) The protein levels of MEK/ERK signal pathway factors were suppressed by Skullcapflavone I, and TPM1 silencing reversed the effect of Skullcapflavone I on MEK/ERK signal pathways; B) the protein levels of NF-kB signal pathway factors were inhibited by Skullcapflavone I, and TPM1 silencing reversed the effect of Skullcapflavone I on NF- $\mathrm{kB}$ signal pathway. 1-control, 2- Skullcapflavone I. 3- Skullcapflavone I + siNC, 4- Skullcapflavone I + si-TPM1.

and $\mathrm{I} \kappa \mathrm{Ba}(\mathrm{p}<0.01$ or $\mathrm{p}<0.001)$, but had no effect on the normal substances. Figure 6 further highlighted that Skullcapflavone I significantly down-regulated the protein levels of phosphorylated MEK, ERK and IкBa, and that TPM1 silencing reversed the blocking effect of Skullcapflavone I on these signal pathways. This indicated that Skullcapflavone I blocked the MEK/ERK and NF- $\kappa B$ signal pathways by modulating TPM1 in HCT116 cells.

\section{Discussion}

Herein, we established that Skullcapflavone I suppressed cell proliferation and down-regulated PNCA and Cyclin D1 protein levels. Skullcapflavone I also inhibited miR-107 expression, promoted TPM1 expression by down-regulating miR-107 and then blocked the MEK/ERK and NF- $\kappa B$ signal pathways by regulating TPM1 in HCT116 cells.

Traditional herbs are used as adjunct therapy in the treatment of cancer, including CRC [25]. It has been suggested that Spica Prunellae (EESP) induces CRC cell apoptosis and suppresses cell proliferation and tumor angiogenesis [26].
Liang et al. then reported that Sophoridine (SRI) extracted from Saphora alopecuroides L seeds exerted anti-CRC effects by inhibiting cell viability and increasing apoptosis in SW480 cells [27]. In addition, although Skullcapflavone I and II are bioactive components of $S$. baicalensis and are reported to inhibit cell proliferation in prostate cancer and hepatocellular carcinoma cells $[28,29]$, Skullcapflavone I influence on $\mathrm{CRC}$ cells proliferation remains unclarified.

Herein, we determined that Skullcapflavone I suppresses cell viability and the expression of cell-cycle associated factors, thus exerting an anti-proliferative effect on CRC cells.

Abundant studies have indicated that miR-107 is involved in the development of various cancers [30,31], and also that it has an important role in cell proliferation [32]. For example, Liu et al. recorded that miR-107 promoted colon cancer cell proliferation by targeting prostate apoptosis responde- 4 (PAR4) [33]. Feng et al. then found that miR-107 reduced cyclin-dependent kinase 6 (CDK6) expression, suppressed cell proliferation and induced cell cycle G1 arrest in gastric cancer cells [34]. Herein, Skullcapflavone I down-regulated miR-107 expression and miR-107 over-expression abolished this anti-proliferation of Skullcapflavone I on HCT116 cells.

Further, TPM1 is a member of the highly conserved tropomyosin $(\mathrm{Tm})$ family which is widely distributed in actinbinding proteins for striated and smooth muscle contraction [35]. Recent study also demonstrated that TPM1 was a tumor suppressor inhibiting breast cancer cell growth in vitro [36], and Zhu et al. identified TPM1 as a potential target of miR-21 and recorded that TPM1 over-expression suppressed MCF-7 breast cancer cells anchorage-independent growth [37]. Finally, although Jiang et al. demonstrated that miR-107 promoted osteosarcoma cell proliferation by regulating TPM1 [24], this process had not been investigated in CRC cells.

We therefore assessed the regulatory relationship of Skullcapflavone I, miR-107 and TPM1 in HCT116 cells and established that Skullcapflavone I increased TPM1 protein level by down-regulating miR-107. This confirmed that Skullcapflavone I inhibited cell proliferation by TPM1 and miR-107 regulation.

$\mathrm{MEK} / \mathrm{ERK}$ and NF- $\mathrm{\kappa B}$ are key mediators in the occurrence and development of various cancers [38, 39]. For example, Chow et al. reported that Raf265 suppressed CRC tumor growth by inactivating the MEK/ERK pathway [40]. Raina et al. then determined that silibinin suppressed CRC growth and progression by interfering with NF- $\mathrm{KB}$ activation [41]. We obtained similar results demonstrating that Skullcapflavone I blocked the MEK/ERK and NF- $\kappa B$ signal pathways by regulating TPM1 and thereby affecting CRC cell proliferation.

In conclusion, our combined results demonstrated that Skullcapflavone I inhibited cell proliferation by regulating miR-107 and TPM1 in HCT116 cells. These findings may well supply the theoretical foundation for CRC research and contribute to establishing a new method for CRC treatment. Finally, further studies into Skullcapflavone I effects should prove advantageous. 


\section{References}

[1] FISHER A, BEEKEN RJ, HEINRICH M, WILLIAMS K, WARDLE J. Health behaviours and fear of cancer recurrence in 10969 colorectal cancer (CRC) patients. Psychooncology 2016; 25: 1434-1440. https://doi.org/10.1002/pon.4076

[2] CRNCEC I, PATHRIA P, SVINKA J, EFERL R. Induction of colorectal cancer in mice and histomorphometric evaluation of tumors. Methods Mol Biol 2015; 1267: 145-164. https:// doi.org/10.1007/978-1-4939-2297-0_7

[3] BERRETTA M, BEARZ A, FRUSTACI S, TALAMINI R, LOMBARDI D et al. FOLFOX2 in the treatment of advanced colorectal cancer: a comparison between elderly and middle aged patients. J Chemother 2008; 20: 503-508. https://doi. org/10.1179/joc.2008.20.4.503

[4] PETERS U, BIEN S, ZUBAIR N. Genetic architecture of colorectal cancer. Gut 2015; 64: 1623-1636. https://doi. org/10.1136/gutjnl-2013-306705

[5] ZHAO J, ZHU Y, WANG PP, WEST R, BUEHLER $S$ et al. Interaction between alcohol drinking and obesity in relation to colorectal cancer risk: a case-control study in Newfoundland and Labrador, Canada. BMC Public Health 2012; 12: 94. https://doi.org/10.1186/1471-2458-12-94

[6] LOAIZA-BONILLA A, JENSEN CE, SHROFF S, FURTH E, BONILLA-REYES PA et al. KDR Mutation as a Novel Predictive Biomarker of Exceptional Response to Regorafenib in Metastatic Colorectal Cancer. Cureus 2016; 8: e478. https:// doi.org/10.7759/cureus.478

[7] RODRIGUES D, LONGATTO-FILHO A, MARTINS SF. Predictive Biomarkers in Colorectal Cancer: From the Single Therapeutic Target to a Plethora of Options. BioMed Research International 2016; 2016. 6896024. https://doi. org/10.1155/2016/6896024

[8] CHEN JJ, HUANG CC, CHANG HY, LI PY, LIANG YC et al. Scutellaria baicalensis Ameliorates Acute Lung Injury by Suppressing Inflammation In Vitro and In Vivo. Am J Chin Med 2017; 45: 137-157. https://doi.org/10.1142/ S0192415X17500100

[9] HAI NT, MINH HPT, LE TA, LY HDT, HUU TN et al. Ethanol extracts of Scutellaria baicalensis protect against lipopolysaccharide-induced acute liver injury in mice. Asian Pac J Trop Biomed 2015; 5: 761-767. https://doi.org/10.1016/j. apjtb.2015.07.007

[10] LEE KJ, JUNG PM, OH YC, SONG NY, KIM T, et al. Extraction and Bioactivity Analysis of Major Flavones Compounds from Scutellaria baicalensis Using In Vitro Assay and Online Screening HPLC-ABTS System. J Anal Methods Chem 2014; 2014: 563702. https://doi.org/10.1155/2014/563702.

[11] TSAI PJ, HUANG WC, HSIEH MC, SUNG PJ, KUO YH et al. Flavones Isolated from Scutellariae radix Suppress Propionibacterium Acnes-Induced Cytokine Production In Vitro and In Vivo. Molecules 2015; 21: 15. https://doi.org/10.3390/ molecules21010015

[12] CHANDRASEKARAN CV, THIYAGARAJAN P, DEEPAK $\mathrm{HB}$, AGARWAL A. In vitro modulation of LPS/calcimycin induced inflammatory and allergic mediators by pure compounds of Andrographis paniculata (King of bitters) extract. Int Immunopharmacol 2011; 11: 79-84. https://doi. org/10.1016/j.intimp.2010.10.009
[13] PARK EJ, ZHAO YZ, LIAN L, KIM YC, SOHN DH. Skullcapflavone I from Scutellaria baicalensis induces apoptosis in activated rat hepatic stellate cells. Planta Med 2005; 71: 885. https://doi.org/10.1055/s-2005-871280

[14] WANG WX, RAJEEV BW, STROMBERG AJ, NA R, TANG $\mathrm{G}$ et al. The expression of microRNA miR-107 decreases early in Alzheimer's disease and may accelerate disease progression through regulation of beta-site amyloid precursor protein-cleaving enzyme 1. J Neurosci 2008; 28: 1213-1223. https://doi.org/10.1523/JNEUROSCI.5065-07.2008

[15] WANG WX, WILFRED BR, MADATHIL SK, TANG G, HU Y et al. miR-107 regulates granulin/progranulin with implications for traumatic brain injury and neurodegenerative disease. Am J Pathol 2010; 177: 334-345. https://doi. org/10.2353/ajpath.2010.091202

[16] TAKAHASHI Y, FORREST AR, MAENO E, HASHIMOTO T, DAUB CO et al. MiR-107 and MiR-185 can induce cell cycle arrest in human non small cell lung cancer cell lines. PLoS One 2009; 4: e6677. https://doi.org/10.1371/journal. pone.0006677

[17] CHEN PS, SU JL, CHA ST, TARN WY, WANG MY et al. miR-107 promotes tumor progression by targeting the let7 microRNA in mice and humans. J Clin Invest 2011; 121: 3442-3455. https://doi.org/10.1172/JCI45390

[18] ZHANG L, MA P, SUN LM, HAN YC, LI BL et al. MiR-107 down-regulates SIAH1 expression in human breast cancer cells and silencing of miR-107 inhibits tumor growth in a nude mouse model of triple-negative breast cancer. Mol Carcinog 2016; 55: 768-777. https://doi.org/10.1002/ mc. 22320

[19] LAM CY, YIP CW, POON TC, CHENG CK, NG EW et al. Identification and characterization of tropomyosin 3 associated with granulin-epithelin precursor in human hepatocellular carcinoma. PLoS One 2012; 7: e40324. https://doi. org/10.1371/journal.pone.0040324

[20] LAM CY, YIP CW, POON TCW, CHENG CKC, NG EW et al. Identification and characterization of tropomyosin 3 associated with granulin-epithelin precursor in human hepatocellular carcinoma. PLoS One 2012; 7: e40324. https://doi. org/10.1371/journal.pone.0040324

[21] LIVAK KJ, SCHMITTGEN TD. Analysis of relative gene expression data using real-time quantitative PCR and the 2(-Delta Delta C(T)) Method. Methods 2001; 25: 402-408. https://doi.org/10.1006/meth.2001.1262

[22] WANG J, GUAN J, LU Z, JIN J, CAI Y et al. Clinical and tumor significance of tropomyosin-1 expression levels in renal cell carcinoma. Oncol Rep 2015; 33: 1326-1334. https://doi. org/10.3892/or.2015.3733

[23] PAN H, GU L, LIU B, LI Y, WANG Y et al. Tropomyosin-1 acts as a potential tumor suppressor in human oral squamous cell carcinoma. PLoS One 2017; 12: e0168900. https:// doi.org/10.1371/journal.pone. 0168900

[24] JIANG R, ZHANG C, LIU G, GU R, WU H. MicroRNA-107 Promotes Proliferation, Migration, and Invasion of Osteosarcoma Cells By Targeting Tropomyosin 1. Oncol Res 2017; 25: 1409-1419. https://doi.org/10.3727/09650401 $7 X 14882829077237$ 
[25] ZHONG LL, CHEN HY, CHO WC, MENG XM, TONG Y. The efficacy of Chinese herbal medicine as an adjunctive therapy for colorectal cancer: a systematic review and metaanalysis. Complement Ther Med 2012; 20: 240-252. https:// doi.org/10.1016/j.ctim.2012.02.004

[26] LIN W, ZHENG L, ZHUANG Q, ZHAO J, CAO Z et al. Spica prunellae promotes cancer cell apoptosis, inhibits cell proliferation and tumor angiogenesis in a mouse model of colorectal cancer via suppression of stat3 pathway. BMC Complement Altern Med 2013; 13: 144. https://doi. org/10.1186/1472-6882-13-144

[27] LIANG L, WANG XY, ZHANG XH, JI B, YAN HC et al. Sophoridine exerts an anti-colorectal carcinoma effect through apoptosis induction in vitro and in vivo. Life Sci 2012; 91: 1295-1303. https://doi.org/10.1016/j.lfs.2012.09.021

[28] BONHAM M, POSAKONY J, COLEMAN I, MONTGOMERY B, SIMON J et al. Characterization of chemical constituents in Scutellaria baicalensis with antiandrogenic and growth-inhibitory activities toward prostate carcinoma. Clin Cancer Res 2005; 11: 3905-3914. https://doi. org/10.1158/1078-0432.CCR-04-1974

[29] HOU H, LI D, QIN Q, WEI Z, LI Q et al. Flavone A from Skullcap inhibited human hepatocellular carcinoma cell (BEL-7402) and enhanced cytotoxicity of anti-cancer drugs in vitro. Chin J Clin Pharmacy 2000; 9: 166-168.

[30] WANG Y, CHEN F, ZHAO M, YANG Z, ZHANG S et al. MiR-107 suppresses proliferation of hepatoma cells through targeting HMGA2 mRNA 3'UTR. Biochem Biophys Res Commun 2016; 480: 455-460. https://doi.org/10.1016/j. bbrc.2016.10.070

[31] ZHOU C, LI G, ZHOU J, HAN N, LIU Z et al. miR-107 activates ATR/Chk1 pathway and suppress cervical cancer invasion by targeting MCL1. PLoS One 2014; 9: e111860. https:// doi.org/10.1371/journal.pone.0111860

[32] ZHANG JJ, WANG CY, HUA L, YAO KH, CHEN JT et al. miR-107 promotes hepatocellular carcinoma cell proliferation by targeting Axin2. Int J Clin Exp Pathol 2015; 8: 51685174 .
[33] LIU F, LIU S, AI F, ZHANG D, XIAO Z et al. miR-107 promotes proliferation and inhibits apoptosis of colon cancer cells by targeting prostate apoptosis responde-4 (Par4). Oncol Res 2017; 25: 967-974. https://doi.org/10.3727/09650401 6X14803476672380.

[34] FENG L, XIE Y, ZHANG H, WU Y. miR-107 targets cyclindependent kinase 6 expression, induces cell cycle G1 arrest and inhibits invasion in gastric cancer cells. Med Oncol 2012; 29: 856-863. https://doi.org/10.1007/s12032-011-9823-1

[35] COLPAN M, TOLKATCHEV D, GROVER S, HELMS GL, CORT JR et al. Localization of the Binding Interface between Leiomodin-2 and $\alpha$-Tropomyosin. Biochim Biophys Acta 2016; 1864: 523-530. https://doi.org/10.1016/j.bbapap.2016.02.009

[36] HAFEZ MM, HASSAN ZK, ZEKRI AR, GABER AA, AL REJAIE SS et al. MicroRNAs and metastasis-related gene expression in Egyptian breast cancer patients. Asian Pac J Cancer Prev 2012; 13: 591-598.

[37] ZHU S, SI ML, WU H, MO YY. MicroRNA-21 targets the tumor suppressor gene tropomyosin 1 (TPM1). J Biol Chem 2007; 282:14328. https://doi.org/10.1074/jbc.M611393200

[38] LI L, ZHAO GD, SHI Z, QI LL, ZHOU LY et al. The Ras/Raf/ MEK/ERK signaling pathway and its role in the occurrence and development of HCC. Oncol Lett 2016; 12: 3045-3050. https://doi.org/10.3892/ol.2016.5110

[39] POMA P, LABBOZZETTA M, D’ALESSANDRO N, NOTARBARTOLO M. NF- $\kappa B$ Is a Potential Molecular Drug Target in Triple-Negative Breast Cancers. OMICS 2017; 21: 225-231. https://doi.org/10.1089/omi.2017.0020

[40] CHOW AK, CHENG NS, LAM CS, NG L, WONG SK et al. Preclinical analysis of the anti-tumor and anti-metastatic effects of Raf265 on colon cancer cells and CD26(+) cancer stem cells in colorectal carcinoma. Mol Cancer 2015; 14: 80. https://doi.org/10.1186/s12943-015-0352-y

[41] RAINA K, AGARWAL C, AGARWAL R. Effect of Silibinin in Human Colorectal Cancer Cells: Targeting the Activation of NF- $\mathrm{BB}$ Signaling. Mol Carcinogen 2013; 52: 195-206. https://doi.org/10.1002/mc.21843 